\title{
EFFECT OF SOME NATURAL FEED ADDITIVES TO SUBSTITUTE ANTIBIOTIC AS GROWTH PROMOTERS ON GROWTH PERFOMANCE, CARCASS CHARACTERISTICS AND ECONOMIC EFFICIENCY OF BROILER CHICKS:1- PROPOLIS
}

\author{
M.M. Hamed; A.I. El-Faham; F. Abd El-Azeem and N.M. El-Medany \\ Poultry Production Dept., Fac. of Agric., Ain Shams Univ., Egypt.
}

\section{SUMMARY}

A study was conducted to determine the effect of three different levels of propolis (PR) and antibiotic (Erythromycin, ER) in diets on performance, carcass characteristics, carcass parts and economical evaluation in broiler chicks. A total of 150 one day oldCobb chicks were weighed and randomly allocated into a completely randomized design (five treatments, three replicate groups, ten chicks in each group). The experimental diets were as follows; basal diet without supplementation (control), $275 \mathrm{~g} \mathrm{ER/ton} \mathrm{(T1),} 500 \mathrm{~g} \mathrm{PR/ton} \mathrm{(T2),} 1000 \mathrm{~g}$ PR/ton (T3) and $2000 \mathrm{~g}$ ER/ton (T4). The main results obtained can be summarized as follows: chicks fed basal diets supplemented with PR or ER significantly $(\mathrm{P} \leq 0.05)$ increased body weight and body weight gain. Average of feed intake was not affected by adding ER or PR during overall experiment period (1-35 days) of age. The best feed conversion ratio, calorie and protein conversion ratio were recorded for the groups supplied with different levels of PR (T2-4). Carcass characteristics (carcass \% and total edible parts $\%$ ) and carcass parts \% (Breast, thigh, drumstick and wing \%) were non-significantly different for all treatment groups except abdominal fat $\%$, liver $\%$, gizzard $\%$, heart $\%$ and giblets $\%$. Supplementation of $275 \mathrm{~g}$ ER/ton (T1), $500 \mathrm{~g}$ PR (T2) and $1000 \mathrm{~g}$ PR/ton (T3) to basal diet the economical efficiency by $28.3,16.8 \%$ and $6.8 \%$ as compared to the control diet. In conclusion, supplemental $275 \mathrm{~g} \mathrm{ER/ton}$ or $500 \mathrm{~g}$ PR/ton to broiler chick diets had a positive effect on growth performance and economical efficiency.

Keywords: Propolis, Erythromycin, Growth and broiler chicks.

\section{INTRODUCTION}

Antibiotic as a growth promoters (AGP) have been used for many years in poultry industry and have proved to be an effective way of enhancing poultry health status, disease prevention, uniformity, production efficiency and growth promotion (Bedford, 2000). Recently, the US Food and Drug Administration has issued an order to prohibit the use of certain antimicrobial drugs in food animals effective, FDA (2012). Therefore, the poultry industry is now facing a great challenge to maintain production performance of birds due to increased feed costs and the restriction of antimicrobial use in feeds. On the other hands, several studies have demonstrated that the potential alternative feed additives to AGP include; directed microbials (Salim et al., 2013), different herbs (El-Fahamet al., 2015), or spices (El-Faham et al., 2014) and organic acids (Thompson and Hinton, 1997), prebiotics (Bengmark, 2001), different dietary enzymes (Angel et al., 2011), Propolis and bee pollen (Katarzyna et al., 2012). Among them, Propolis (bee glue) is a product of the honey bees used to protect hive, larvae and themselves from the various microorganisms like virus, bacteria and fungi (Zumrut et al., 2005). The chemical composition of propolis depends on the ecological characteristics of collection zone and the number of chemical compounds in its structure varies between 70 to 80 and the most biological active components are flavonoids, hydroxy flavonoids, dehydro-calcons, alpha and beta amylase, ketones, phenols, vitamins, minerals, transhydrogenase, nucleic, aldehydes, cinnamic acid, sterols, terpenoids, amino-acids, insoluble parts and unidentified materials (Stangaciu, 1999).

Therefore, many researchers tried to find some natural feed additives such as propolis to be used in poultry farms to reduce the expected harmful effects (Hegazi et al., 2012 and Abdel-Kareem and ElSneikh, 2016). Supplemental propolis has received special attention from the broiler producers to promote growth performance; the balance and quality of the intestinal microflora for the host, but the efficacy of these products varies according to their production procedure and practical application 


\section{Hamed et al.}

(Khojasteh and Shivazad, 2006). Many researchers explained the effeteness and the physiological role of propolis against a variety of viruses (Amoros et al., 1994), moulds (Miyataka et al., 1997), bacteria(Velikova et al., 2000) and fungi (Murad et al., 2002). Also, the results of many previous reports demonstrated that the use of propolis has a beneficial influence on body weight gain, feed consumption, conversion ratio, and productive performance in different poultry species (Roodsariet al., 2004; El-Hanoun et al., 2007; Galal et al., 2008; Seven et al., 2009; Guclu-Kacaoglu, 2010; Seven et al., 2011 and El-Neney et al., 2014).

By contrast, other researchers did not find any positive effects of using dietary propolis on growth performance of broiler chicks (Tatli Seven and Seven, 2008 and Mahmoud et al., 2013). Therefore, a feeding trial was conducted to investigate the supplementation of Propolis as an alternative to AGP on growth performance, carcass characteristics and economic efficiency of broiler chicks.

\section{MATERIALS AND METHODS}

The experiment was implemented in Poultry Nutrition Farm, Poultry Production Department, Faculty of Agriculture, Ain Shams University, Koliobia, Egypt, in order to investigate the effect of propolis supplementation as a natural growth promoting substance on growth performance, carcass characteristics and economic efficiency of broiler chicks.

A total of 150 one-day old Cobb broiler chicks were randomly divided into five equal groups, each group contained three replicates of 10 chicks. The chicks were grown in battery cages and kept under similar environmental and managerial condition during 1-35 days of age. Feed and water were supplied adlibitum. The composition and calculated analysis of the basal diet (starter 1-14 days, grower 15-28 days and finisher diets 29-35 days of age) are presented in Table 1.

Propolis was obtained from the Honeybee Research Section, Faculty of Agriculture, Ain Shams University, Egypt. Propolis were homogenized to be a fine powder and packed in polyamidepolyethyline bags and stored at $-4^{\circ} \mathrm{c}$ until use. Treatments were prepared by mixing the growth promoters (Antibiotic or Propolis) into the basal diet at the rate of $0 \%$ (control), $275 \mathrm{~g} /$ ton Erythromycin (T1) or $500 \mathrm{~g} /$ ton (T2), $1000 \mathrm{~g} / \mathrm{ton}$ (T3) and $2000 \mathrm{~g} / \mathrm{ton}$ (T4) of Propolis. The data of growth performance parameters including individual body weight and feed intake which were determined weekly intervals. Body weight gain $(\mathrm{g})$ and feed conversion ratio ( $\mathrm{g}$ feed: $\mathrm{g}$ gain) were calculated. Mortality of birds was recorded at the day when it occurred.

Protein conversion ratio (PCR, g protein / g gain); energy conversion ratio (ECR, kcal/g gain) and performance index were also calculated. The PCR was calculated as grams of protein intake per grams of weight, whereas the ECP was calculated as total ME intake /weight gain (gram) and performance index was calculated according to North (1981).

At 35 days of age, four birds from each treatments were randomly chosen ( 2 hens and 2 cocks), weighed and then slaughtered,after complete bleeding and feather removal, carcass, liver, heart, gizzard, abdominal fat and neck were weighed and their weight was recorded as percentage of body weight. Each carcass was split into its cuts, breast, drumstick, thighs and wings were weighed and expressed as percentages of carcass weight.

A production cost analysis and economic evaluation was carried out for all dietary treatments in an attempt to investigate effects of Propolis inclusion on feeding costs.

Statistical analysis: Data were statistically analyzed using the General Linear Model Procedure of analysis (SAS, 2004). Duncan's multiple range test (Duncan, 1955), was used to test differences within means of treatments, while level of significance was set typically at minimum $(\mathrm{P} \leq 0.05)$.

The statistical model used for analyzing data was as following:

$$
\mathrm{Y}_{\mathrm{ij}}=\mathrm{M}+\mathrm{T}_{\mathrm{i}}+\mathrm{e}_{\mathrm{ij}}
$$

Where:

$\mathrm{Y}_{\mathrm{ij}}=$ observation of the parameter measured.

$\mathrm{T}_{\mathrm{i}}=$ effect of treatment (I : 1 to 5).

$\mathrm{M}=$ overall mean.

$\mathrm{e}_{\mathrm{ij}}=$ random error. 


\section{RESULTS AND DISCUSSION}

\section{Productive performance:}

\section{Live body weight and weight gain:}

The live body weight and weight gain of broiler as effected by dietary treatments are illustrated in Table (2). It is worth to note that the chicks fed control diet during studied periods (1- 14, 15-28, 29- 35 and 1 - 35 days) reflected the lowest significant $(\mathrm{P}<0.05)$ results in both live body weight and weight gain compared with the other treatments $\left(\mathrm{T}_{1-4}\right)$. However, body weight during the starting period (1-14 days), chicks of $\mathrm{T}_{3}$ increased by $5.8 \%$ (344.80 versus 364.97); during starting and growing period (1 28 days), chicks of $\mathrm{T}_{2}$ increased by $10.52 \%$ (1143.50 versus / 1263.83) and during whole experimental period (1-35 days), chicks of increased by $13.5 \%$ (1569.08 versus 1780.37 ) compared with chicks fed control diet.

$\mathrm{T}_{1} \mathrm{On}$ the other hand, chicks fed erythromycin diet gave slightly higher live body weight $(353.70$, 1192.87 and $1709.11 \mathrm{~g}$ )for different growing period respectively compared to those fed control diet, the differences were statistically not significant excepted in 35 days of age. In the same order, during whole the experimental period (1-35 days), responses of chicks fed different dietary treatments showed that chicks fed $\left(\mathrm{T}_{1-4}\right)$ diets supported the highest body weight than those fed control diet. The corresponding figures were $(1709.11,1661.63,1718.48$ and $1780.37 \mathrm{~g})$ respectively and the differences were significant compared with those fed control diet $(1569.08 \mathrm{~g})$. On the other hand, the addition of propolis to experimental diets $\left(\mathrm{T}_{2-4}\right)$ supported higher live body weight gain significantly $(\mathrm{P}<0.05)$ compared with those fed control diet and the improvement in body weight increased slightly as the level of propolis increased. It was obvious from Table (2), that the body weight gain / g) confirmed this trend and the corresponding values were 1626.00, 1681.52 and $1744.57 \mathrm{~g}$. When chicks were fed diets supplemented with 500, 1000 and $2000 \mathrm{~g}$ propolis/ton respectively during whole experimental period (1-35 days) of age.

Also, during finishing period (29-35 days) chicks fed diet containing $2000 \mathrm{~g}$ propolis /ton gained more weight and gave the best figures $(588.63 \mathrm{~g})$ than those fed diets containing 500 or $1000 \mathrm{~g}$ propolis /ton (397.80 and $490.00 \mathrm{~g}$ ) respectively, however, differences among treatments were significant. Similar observations were reported by other investigators (Shalmanyand Shivazad, 2006; Tatli Seven et al., 2008 and Babaei et al., 2016). They recorded the beneficial effect of propolis on growth performance and immune response in poultry. In addition, Effat Shreif and Amina El-Saadany (2017) reported that live body weight and body weight gain were significantly increased with increasing of propolis level (150, 300 and $450 \mathrm{~g}$ propolis/ton) in Bandarah chicks diet (0-12)wks of age. On the other hand, these findings are in contrast with the results obtained by Mahmoud et al. (2013) and Klecyek et al. (2014), they concluded that feeding broiler chicks diets supplemented with propolis had no beneficial effects on body weight or body weight gain during experimental periods.

\section{Feed intake and feed conversion:}

The results in Table (2) show the relationship between dietary growth promoters (Erytheromycin and propolis) and feed intake and feed conversion ratio. During starting period, the supplementation of ertheromycin or propolis to experimental treatment, except $\left(T_{3}\right)$ led chicks to consume less feed compared with those fed control diet, however, the differences failed to be significant. In the same order, during growing, finishing and whole experimental periods, broiler chicks fed different dietary treatments showed no negative effects on feed intake and the differences between treatments were significant (Table 2).

Moreover, the response of feed intake to propolis levels was not significant and the corresponding values were $2649.30,2739.50$ and $2839.80 \mathrm{~g}$ when chicks were fed diets containing 500, 1000, and $2000 \mathrm{~g}$ propolis / ton, respectively and the reduction in feed intake increased slightly as the level of propolis decreased. Besides, the differences between treatments were insignificant. Similar observations were reported by other investigators, Effat Shreif and Amina El-Saadany (2017) in chicks, Conogullari et al. (2009) in Japanese quails and Abdel-Rahman and Mosaad (2013) in Muscovy duck. They concluded that dietary propolis of birds had no significant effect on feed consumption. These findings are in contrast with the results obtained by Attia et al. (2014) and El-Neneyet al. (2016), they concluded that supplemental propolis in chicks diets caused reduction in feed consumption compared with control group. 


\section{Hamed et al.}

Feed conversion ratio (FCR), the results showed significant differences between broiler chicks fed diets containing different levels of propolis $\left(\mathrm{T}_{2-4}\right)$ compared with those fed control diet.

Moreover, feeding diets containing 500, 1000 or $2000 \mathrm{~g}$ propolis/ton $\left(\mathrm{T}_{2-4}\right)$ gave the best FCR (being the same figure 1.63,) compared the control diet (1.83) or erythromycin diet $\left(1.67, \mathrm{~T}_{1}\right)$ and in most cases differences were significant. These results are in agreement with those reported by many investigators Galal et al. (2008), Abdel-Kareem and El-Sheikh (2015) and EffatShrief and Amina ElSaadany (2017).

They concluded that inclusion of propolis in poultry diets reflected a positive effect on FCR and birds fed propolis diets were more efficient in converting their food into body weight gain (growing chicks) or egg production (laying hens) compared with those fed control diets.

\section{Health condition and mortality rate:}

Using different sources of growth promoters (Antibiotic and relatively high level of propolis) in broiler diets had no negative response on health conditions, fatty liver syndrome and mortality rate was found. Under the condition of the present study all birds appeared healthy and total mortality rate was $2.67 \%$ (4 birds) during the total experimental period (35 days). Hence, it seems that either kind of growth promotors $\left(\mathrm{T}_{1}\right)$ or inclusion of different levels of propolis $\left(\mathrm{T}_{2-4}\right)$ had a positively influenced health conditions and mortality rate. Furthermore, the mode of action of propolis may be due to a strong effect of antibacterial action and the presence of micronutrients, which have positive effect on bird's health (Canogullariet al., 2009).

\section{Energy $(E C R)$ protein $(P C R)$ conversion ratio and performance index (PI):}

Significant differences were observed in ECR. PCR and PI within experimental treatments during the whole experimental period (Table 3). ECR figures ranged between 5.70 and 5.06, while those of PCR ranged between 0.36 and 0.32 . In the same order, the figures of ECR and PCR indicted significant differences between chicks fed diets containing propolis $\left(\mathrm{T}_{2-4}\right)$ compared with those fed control diet. The best ECR and PCR was detected for the chicks fed diets incorporated with $500 \mathrm{~g} /$ ton propolis (5.06 and 0.32) respectively. However, the worst figures were found in chicks fed control diet and the corresponding figures were 5.70 and 0.36 respectively. On the other hand, feeding diets containing different sources of growth promoters $\left(\mathrm{T}_{1-4}\right)$, broiler chicks gave significant higher values of PI were 101.37, 102.8, 105.54 and 109.38 versus 86.32, (control group) respectively with significant differences. These resultsare in harmony with finding of Effat Shrief and Amina El-Saadany (2017) who mentioned that supplemented chicks diet with different levels of propolis improved growth performance, physiological, immunological, microbiological and anti-oxidative status.

\section{Carcass characteristics and carcass parts percentages:}

Tables (4-5) shows the effect of different treatments on carcass characteristics and carcass parts of both sexes slaughtered at the end of 35 days of age. The obtained data showed that there were insignificant differences in carcass percentages and total edible parts percentages (Hot carcass weight + giblets weight). Chicks fed propolis diet $\left(\mathrm{T}_{4}\right)$ reflected the highest carcass and total edible parts percentages compared with other treatments. However, carcass \% increased by $5.38 \%(73.88$ versus $70.11 \%$ ) compared with that fed control diets and total edible parts \% showed similar trend (78.05 versus $74.34 \%$ ). Besides, the differences between the two treatments were insignificant. In the same order, the figures of giblets \% (liver + gizzard + heart $\%$ ) indicated significant differences between chicks fed diet containing $1000 \mathrm{~g} /$ ton propolis $\left(\mathrm{T}_{3}\right)$ compared with those fed antibiotic diet $\left(\mathrm{T}_{1}\right)$ or $500 \mathrm{~g}$ / ton propolis $\left(\mathrm{T}_{2}\right)$ and the corresponding figures ranged between 3.78 and $4.55 \%$ and in most cases differences between treatments were significant. These findings are in contrast with the results obtained by Attia et al. (2014), andEffat Sherif andAmina El-Saadany (2017) who reported that propolis supplementations have been shown to increase carcass weight, yield and dressing percentage in chickens. However, supplied chicks diets with propolis had no significant effects on gizzard, heart and liver respectively. On the other hand, the obtained data are agreement with those reported by (Tatli Seven et al. (2008) and Mahmoud et al., (2013), they conclude that chest parts neck, legs, wings, and chilled percentage were not effects by propolis treatment in broiler chicks.

\section{Economical evaluation:}

Data for economical evaluation are summarized in Table (6). The results of net return, economical efficiency (EE) and relative economic efficiency (REE) estimated for experimental treatments are based on the recent of local market for feed ingredients and selling price of live broiler chicks during March 2017. The average cost/ton of final experimental diets (starter, grower and finisher) are shown 
in Table (1). It was clear that using growth promoters (Antibiotic and propolis) $\left(\mathrm{T}_{1-4}\right)$ relatively increased that cost/ton final diets compared with control. The cost increasing in starter, grower and finisher diets were more pronounced by using propolis compared by using Antibiotic. This difference could be explained on the basis of the high price of propolis for $1 \mathrm{~kg}$ (1000LE) and the levels using (500 to $2000 \mathrm{~g} /$ ton).

As shown in Table (6), it is interesting to state that under the condition of the present study, the chicks fed diet contained propolis $\left(\mathrm{T}_{4}\right)$ gave the lowest economical and relative efficiency values being 32.51 and $87.6 \%$ respectively. This may be due to total feed cost/chick and average feed intake. Whereas, chicks fed diet contained Antibiotic $\left(\mathrm{T}_{2}\right)$ had the best corresponding values being 47.61 and $128.3 \%$, respectively. On the other hand, and in general, using 500 or $1000 \mathrm{~g} /$ ton propolis (T2 or T3) increased economic efficiency and relative economic efficiency of broiler chicks compared with those fed the control diet and the corresponding increasing values in REE were 16.8 and $6.8 \%$ respectively. Similar observations have been reported by Effat Shreif and Amina El-Saadany (2017). They concluded that, propolis supplementation at any levels (150, 300 and $450 \mathrm{~g}$ propolis/ton) to chicks diet improved net revenue and economical efficiency and chicks fed diet supplied with $450 \mathrm{~g}$ propolis/ton diet were recorded the best economic efficiency.

\section{CONCLUSION}

In conclusion, broiler chicks fed on basal diet supplemented with $275 \mathrm{~g} /$ ton erythromycin or 500 $\mathrm{g} /$ ton propolis, would have a positive effect on the economical efficiency of broiler chicks, without any adverse effect on productive performance or carcass traits of the broilers comparable to the control.

\section{REFERENCES}

Abdel-Kareem, A.A. and T.M. El-Sheikh (2015). Impact of supplementing diets with Propolis on productive performance egg quality traits and some hematological variables of laying hens. J. Anim Phvsiol. Anim. Nutr., 28:1-10.

Abdel-Kareem, A.A.A. and T.M. El-Sheikh (2016). Impact of supplementing diets with propolis on productive performance, egg quality traits and some hematological variables of laying hens. J. of Anim. Physi. and Anim. Nutrition. 1-8.

Abdel-Rahman, M.A. and G.M. Mosaad (2013). Effect of propolis as additive on some behavioral patterns, performance and blood parameters in Muscovy broiler Ducks. J. Adv. Vete.Res.,3:64-68.

Amoros. M.;E. Lurton; J. Boustic; L. Girre;F. Sauvager; M. Cormier(1994). Comparison of the antiherpes simplex virus activities of propolis and 3-methyl- but-2-enylcaffeate. Journal of Natural Products 57, 644-647.

Angel, C.R.; W. Saylor; S.L. Vieira and N. Ward (2011). Effects of a nanocomponent protease on performance and protein utilization in 7 to 22 days- old broiler chickens. Poultr. Sci., 90: 22812286.

Attia, Y.A.; A.E. Abd Al-Hamid; M.S. Ibrahim; M.A. Al-Harthi; F. Bovera and A. El-Naggar (2014). Productive performance, biochemical and hematological traits of broiler chicks supplemented with propolis, bee pollen and mannan oligosaccharides continuously or intermittently. Livest. Sci.,164:87-95.

Babaei, S.;S. Rahimi;M.A.K. Torshizi;G. Tahmasebi and S. N. KhaleghiMiran (2016). Effects of propolis royal jelly, honey and bee pollen on growth Performance and immune system of Japanese quails. Vet. Res.7 (1):13-20.

Bedford, M. (2000). Removal of antibiotic growth promoters from poultry diets. Implications and strategies to minimize subsequent problems. World's Poult. Sci., J. 56: 347-354.

Bengmark, S. (2001). Pre-Pro-and symbiotic. Current opinion in Clinical Nutri. and Metab. Care. 4: 571-579.

Conogullari, S.; M. Baylan; N. Sahinler and A. Sahen (2009). Effects of propolis and pollen supplementations on growth performance and body components of Japanese quails (Coturnix coturnix japonica). Archive fur Geflugelkunde. 73: 173-178. 


\section{Hamed et al.}

Duncan, D.B. (1955). Multiple ranges and multiple F test. Biometrics, 11: 1-42.

Effat, Y. Shreif and Amina S. El-Saadany (2017). Effect of supplementing diet with propolis on bandarahchicks performance. Egypt. Poult. Sci. I: 169-184.

El-Faham, A.I.; A.M.H. Ahmed and M.H.S. El-Sanhoury (2015). Thyme leaves or its extracted oil for enhancing productive and physiological status of broiler chickens. Egypt. Poult. Sci. 35: 215-236.

El-Faham, A.I.; Nematallah, G.M. Ali, and Hayam, M.A.A. El-Maaty (2014). Effect of using some natural feed additives to substitute antibiotic growth promoters on performance and blood parameters of broilers. Egypt. Poult. Sci., 34: 735-750.

El-Hanoun, A.M.; Kamel, K.I. El-Sebaie;M.S. James; H.A. Gad (2007). Effect of Egyptian propolis supplementation on productive, reproductive performance and some hematobiochemical parameters and steroid hormones of female rabbits Kame during winter and summer seasons. 4th World Poult. Con. 27-30 March, Sharm 1-Sheikh, Egypt.

El-Neney, Battaa, A.M.; Nasra B. Awadien and Y. Z. Eid (2016). The use of propolis as a source of natural additive $s$ to improve the productive performance and immune system of chickens.1-Effect on growing Dokki 4. $9^{\text {th }}$ Int. Poult. Conf. Proc. 7-10 November, Hurghada, Red Sea, Egypt

El-Neney, Battaa; N.B. Awadien andY.Z. Eid (2014). The use of propolis as a source of natural additives to improve the productive performance and immune system of chicken's local. 1-Effect on laying hen performance. 7 International Poultry Conference- Proceeding 58-79.

FDA (2012). The Food and Drug Administration. U.S. Department of Health and Human Services. New Anim. Drugs; Cephalosporin Drugs; Extra Abel Animal Drug Use; order of prohibition Docket No. FDA.2005-N-0326.

Galal, A.; Abd El-Motaal, A.M.; Ahmed, Krel A.M.H.; Zaki, T.G., (2008). Productive Be performance and immune response of laying hens as affected by dietary propolis supplementation. International Journal of Poultry Science 7, 272-278.

Guclu-Kocaoglu, B., (2010). Effect of dietary addition of propolis and caffeic acid on the growth performance, production $\mathrm{M}$ and hatching performance, egg quality and some biochemical parameters of quail (CoturnixCoturnix Japonica). Ere University Journal of Health Science 19, 94 104 .

Hegazi, A.; A.M. Abdou andF.A. Allah (2012). Egyptian propolis 9-its effect on chicken productivity and immune response against Newcastle disease vaccine. British Journal of Poultry Sciences I, 2530.

Katarzyna, K.; M. Katarzyna; M. Wlodzimierz and M. Danuta (2012). The effect of diet supplementation with propolis and bee pollen on the physicochemical properties and strength of tibial bones in broiler chickens. ArchivTierzucht 1: 97-103.

Khojasteh, S.S. andM. Shivazad (2006). The effect of diet Propolis supplementation on Ross broiler chicks performance. International Journal of Poultry Science 5, 84-88.

Kleczek, K.; E. Wawro; K. Wawro; W. Makowski; D. Murawska and M. Wawro (2014). The effect of dietary propolis supplementation on the growth performance of broiler chickens. Poul. J. Sci., 29 (2):105-117.

Mahmoud, U.T.; M.A., Abdel-Rahman and M.H.A, Darwish (2013). The effect of Chinese propolis supplementation on Ross broiler performance and carcass characteristics. J. of advanced vet. Research 3: 154-160.

Miyataka, H.; M. Nishiki;H. Matsumoto; T. Fujimoto; M. Matsuka andT., Satoh (1997). Evaluation of propolis. I. Evaluation of Brazilian and Chinese propolis by enzymatic and physicochemical methods. Biological and Pharmaceutical Bulletin 20, 496-501.

Murad, J.M.; S.A. Calvi; A.M.V.C. Soares; V. Bankova andJ.M. Sforcin (2002). Effect of propolis from Brazil and Bulgaria on fungicidal activity of macrophage against paracoccidioidesbrasiliensis. Journal of Ethnopharmacology 79, 331-334.

North, M.O. and D.D. Bell(1981). Breeder Management. In: "Commercial Chicken Production Manual". 4th Ed., Van Nostrand Reinhold. New York, USA.

NRC (1994). National Research Council. Nutrient Requirements of poultry. $9^{\text {th }}$ Ed. Composition of poultry feedstuffs. National Academy Press, Washington, DC, USA. P.P. 61-75.

Roodsari, M.H.; M. Mehdizadeh; F.B. Kasmani; H. Lotfelahian; F. Mosavi andA.H. Abolghasemi (2004). Effects of oil-extracted propolis on the performance of broiler chicks. Agricultural Sciences and Technology 18, 57-65. 
Salim, H.M.; H.K. Kang; N. Akter; D.W. Kin; J.H. Kim; M.J. Kim; J.C. Na; H.B. Jong; H.C. Choi; O.S. Suh and W.K. Kim (2013). Supplementation of direct-fed microbials as an alternative to antibiotic on growth performance, immune response, ceca microbial population, and ileal morphology of broiler chickens. Poult. Sci. 92: 2084-2090.

SAS (2004). SAS procedure guide version 6. $12^{\text {th }}$ Ed. SAS institute Inc., Cary, NC, and U.C.A.

Seven, I.; P. Tatli Seven andS. Silici (2011). Effects of dietary Turkish propolis as alternative to antibiotic on growth and laying performances, nutrient digestibility and egg quality in laying hens under 13: A heat stress. Revue de MédecineVétérinaire med 162, 186-191. 30.

Seven, P.T.; S. Yilmaz; I. Seven; I.H. Cerci; M.A. Azman andM. Yilmaz (2009). Effects of propolis on selected blood indicators and antioxidant enzyme activities in broilers under heat stress. ActaVeterinaria Brno 78, 75-83.

Shalmany, S.K. and M.Shivazad (2006). The effect of dirt propolis supplementation on Ross broiler chick's performance. Int. J. Pout. Sci., 5:84-88.

Stangaciu, S. (1999). A pitherapy Internet Course Notes, 286 pp. (http://www.apitherapy.com)

Tatli Seven, P. and I. Seven (2008). Effect of dietary Turkish propolis as alternative to antibiotic on performance and digestibility in broilers exposed to heat stress. J. of Applied Anim. Research, 34: 193-196.

TatliSeven P.; I. Seven; M.Yilmaz and U.G. Simsek (2008). The effects of Turkish Propolis on growth and carcass characteristics in broilers under heat stress. Anim. Feed Sci. Technol., 146:137-148.

Thompson, J.L. and M. Hinton (1997). Antibacterial activity of formic acid and propionic acid in the diet of hens on Salmonellas in the crop. Brit. Poult. Sci., 38: 59-65.

Velikova, M.; V. Bankova; I. Tsvetkova;A. Kujumgiev and M.C. Marcucci, (2000). Antibacterial entkaurene from Brazilian propolis of native stingless bees. Fitototerapia 71, 693-696.

Zumrut, A.; Y. Banu and A. Ozge (2005). The effect of propolis supplementation on broiler performance and feed digestibility. Arch. Geflugelk 3: 117-122. 


\title{
Hamed et al.
}

تأثير استخدام بعض منشطات النمو الطبيعية كبديل للمضادات الحيوية على الأداء الإنتاجى وصفات الذبيحة

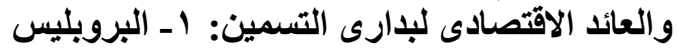

\author{
محمد مصطفى حامد وأحمد إبراهيم الفحام وفتحى عبد العظيم ونبيل محمد المدنى
}

قسم إنتاج الدواجن - كلية النزراعة - جامعة عين شمس - مصر.

أجريت دراسة للتعرف على تأثير إضافة ثلاثة مستويات من البروبليس والمضاد الحيوى (اريثرومايسين) فى العلائق على الأداء

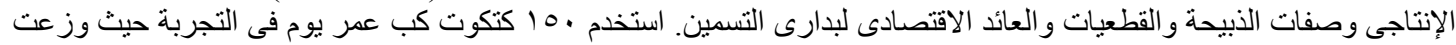

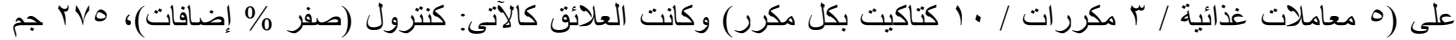

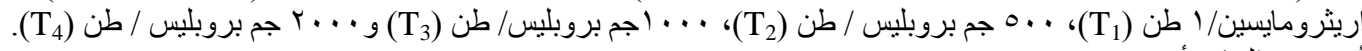

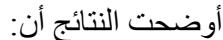

- إضافة البروبليس والمضاد الحيوى الإرثيرومايسين فى علائق بدارى التسمين حسن معنويأ وزن الجسم ومعدل النمو ولم يؤثر على

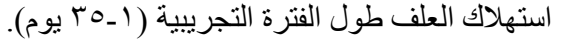

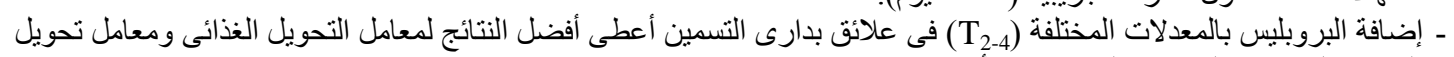
الطاقة و البروتين بالمقارنة بالمعاملات الأخرى.

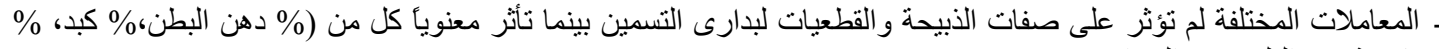

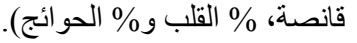

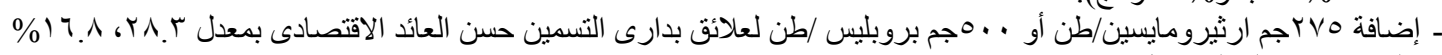

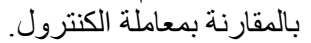

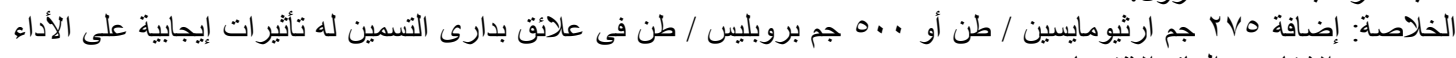

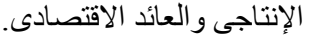


Hamed et al.

Table (2): Effect of dietary treatment on growth performance of broiler chicks (1-35) days of age.

\begin{tabular}{|c|c|c|c|c|c|c|c|}
\hline \multirow[b]{2}{*}{ Items } & \multicolumn{5}{|c|}{ Treatments } & \multirow[b]{2}{*}{ SE } & \multirow{2}{*}{$\begin{array}{l}\text { Significant } \\
\text { of } \\
\text { differences } \\
\end{array}$} \\
\hline & Control & $\mathrm{T} 1$ & $\mathrm{~T} 2$ & T3 & $\mathrm{T} 4$ & & \\
\hline \multicolumn{8}{|l|}{ Body weight (g) } \\
\hline Intial, 1day & 36.03 & 37.00 & 36.30 & 35.97 & 35.80 & 0.22 & NS \\
\hline 14 days & $344.80^{\mathrm{bc}}$ & $353.70^{\mathrm{abc}}$ & $358.67^{\mathrm{ab}}$ & $364.97^{\mathrm{a}}$ & $344.07^{\mathrm{c}}$ & 2.67 & $*$ \\
\hline 28 days & $1143.50^{\mathrm{b}}$ & $1192.87^{\mathrm{ab}}$ & $1263.83^{\mathrm{a}}$ & $1228.83^{\mathrm{a}}$ & $1191.73^{\mathrm{ab}}$ & 13.70 & $*$ \\
\hline 35 days & $1569.08^{c}$ & $1709.11^{\mathrm{ab}}$ & $1661.63^{b c}$ & $1718.48^{\mathrm{ab}}$ & $1780.37^{\mathrm{a}}$ & 22.45 & $*$ \\
\hline \multicolumn{8}{|c|}{ 1-14 days } \\
\hline \multicolumn{8}{|l|}{ Body weight gain (g) } \\
\hline Feed intake $(\mathrm{g})$ & $308.77^{\mathrm{b}}$ & $316.70^{\mathrm{ab}}$ & $322.37^{\mathrm{ab}}$ & $329.00^{\mathrm{a}}$ & $308.26^{\mathrm{b}}$ & 2.66 & $*$ \\
\hline Feed conversion ratio & $389.00^{\mathrm{ab}}$ & $384.63^{\mathrm{ab}}$ & $383.33^{\mathrm{ab}}$ & $400.00^{\mathrm{a}}$ & $367.2^{\mathrm{b}}$ & 3.90 & $*$ \\
\hline (g feed/g gain) & $1.26^{\mathrm{a}}$ & $1.22^{\mathrm{ab}}$ & $1.19^{\mathrm{b}}$ & $1.21^{\mathrm{ab}}$ & $1.19^{\mathrm{b}}$ & 0.01 & $*$ \\
\hline \multicolumn{8}{|c|}{ 15-28 days } \\
\hline \multicolumn{8}{|l|}{ Body weight gain (g) } \\
\hline Feed intake $(\mathrm{g})$ & $798.70^{\mathrm{b}}$ & $839.17^{\mathrm{ab}}$ & $905.17^{\mathrm{a}}$ & $863.47^{\mathrm{ab}}$ & $847.67^{\mathrm{ab}}$ & 12.83 & $*$ \\
\hline Feed conversion ratio & 1278.00 & 1240.43 & 1253.00 & 1313.60 & 1245.90 & 24.29 & Ns \\
\hline (g feed/g gain) & $1.60^{\mathrm{a}}$ & $1.47^{\mathrm{ab}}$ & $1.38^{\mathrm{b}}$ & $1.52^{\mathrm{ab}}$ & $1.47^{\mathrm{ab}}$ & 0.03 & $*$ \\
\hline \multicolumn{8}{|c|}{ 29-35days } \\
\hline \multicolumn{8}{|l|}{ Body weight gain (g) } \\
\hline Feed intake $(\mathrm{g})$ & $425.58^{b}$ & $516.24^{\mathrm{ab}}$ & $397.80^{b}$ & $490.00^{\mathrm{ab}}$ & $588.63^{\mathrm{a}}$ & 23.04 & $*$ \\
\hline Feed conversion ratio & 1144.10 & 1201.00 & 1012.90 & 1025.90 & 1226.70 & 38.83 & NS \\
\hline (g feed/g gain) & $2.69^{\mathrm{a}}$ & $2.37^{\mathrm{ab}}$ & $2.53^{\mathrm{ab}}$ & $2.10^{\mathrm{b}}$ & $2.09^{\mathrm{b}}$ & 0.08 & $*$ \\
\hline \multicolumn{8}{|c|}{ 1-35 days } \\
\hline Body weight gain (g) & & & & & & & \\
\hline Feed intake $(\mathrm{g})$ & $1533.04^{\mathrm{c}}$ & $1672.11^{\mathrm{ab}}$ & $1626.00^{\mathrm{bc}}$ & $1681.52^{\mathrm{ab}}$ & $1744.57^{\mathrm{a}}$ & 22.43 & $*$ \\
\hline Feed conversion ratio & 2811.00 & 2826.00 & 2649.30 & 2739.50 & 2839.80 & 39.07 & NS \\
\hline (g feed/g gain) & $1.83^{\mathrm{a}}$ & $1.67^{\mathrm{ab}}$ & $1.63^{\mathrm{b}}$ & $1.63^{\mathrm{b}}$ & $1.63^{\mathrm{b}}$ & 0.03 & $*$ \\
\hline Mortality rate & $2 / 30$ & $2 / 30$ & $0 / 30$ & $0 / 30$ & $0 / 30$ & & \\
\hline
\end{tabular}

Table (3): Effect of different dietary treatments on calorie conversion ratio, protein conversion ratio, and performance index of broiler chicks (1-35 days of age)

\begin{tabular}{|c|c|c|c|c|c|c|c|}
\hline \multirow[b]{2}{*}{ Items } & \multicolumn{5}{|c|}{ Treatments } & \multirow[b]{2}{*}{ SE } & \multirow{2}{*}{$\begin{array}{c}\text { Significant } \\
\text { of } \\
\text { differences }\end{array}$} \\
\hline & Control & T1 & $\mathrm{T} 2$ & T3 & $\mathrm{T} 4$ & & \\
\hline $\begin{array}{l}\text { Calories conversion ratio } \\
\text { (ECR) }\end{array}$ & $5.70^{\mathrm{a}}$ & $5.27^{\mathrm{ab}}$ & $5.06^{b}$ & $5.10^{b}$ & $5.07^{b}$ & 0.01 & $*$ \\
\hline $\begin{array}{l}\text { Protein conversion ratio } \\
\text { (PCR) }\end{array}$ & $0.36^{\mathrm{a}}$ & $0.34^{\mathrm{ab}}$ & $0.32^{\mathrm{b}}$ & $0.32^{\mathrm{b}}$ & $0.32^{\mathrm{b}}$ & 0.09 & $*$ \\
\hline Performance index $* *$ & $86.32^{\mathrm{b}}$ & $101.37^{\mathrm{a}}$ & $102.8^{\mathrm{a}}$ & $105.54^{\mathrm{a}}$ & $109.38^{\mathrm{a}}$ & 2.59 & $*$ \\
\hline
\end{tabular}

$a, b, c$ means in the same raw with different superscripts in the same raw are significantly different.

*significance, $(p \geq 0.05), \quad$ N.S:non-significant, $\quad * *$ North (1981) 
Table (4): Effect of dietary treatment on carcass characteristics percentages at 35 days of age.

\begin{tabular}{lccccccc}
\hline \multirow{2}{*}{ Items } & \multicolumn{9}{c}{ Treatments } & \multirow{2}{*}{ SE } & $\begin{array}{c}\text { Significant of } \\
\text { differences }\end{array}$ \\
\cline { 2 - 5 } & Control & T1 & T2 & T3 & T4 & & NS \\
Carcass & 70.11 & 70.80 & 69.62 & 69.02 & 73.88 & 1.48 & NS \\
Neck & 5.47 & 5.10 & 5.02 & 5.09 & 5.36 & 0.28 & $*$ \\
liver & $2.18^{\mathrm{a}}$ & $1.85^{\mathrm{ab}}$ & $2.01^{\mathrm{ab}}$ & $2.26^{\mathrm{a}}$ & $1.78^{\mathrm{a}}$ & 0.12 & $*$ \\
heart & $1.55^{\mathrm{bc}}$ & $1.38^{\mathrm{c}}$ & $1.48^{\mathrm{bc}}$ & $1.81^{\mathrm{a}}$ & $1.66^{\mathrm{ab}}$ & 0.03 & $* .52^{\mathrm{b}}$ \\
Giblets part & $0.52^{\mathrm{b}}$ & $0.54^{\mathrm{b}}$ & $0.54^{\mathrm{b}}$ & $0.52^{\mathrm{b}}$ & $0.72^{\mathrm{a}}$ & 0.07 & $*$ \\
Total edible parts** & $4.25^{\mathrm{ab}}$ & $3.78^{\mathrm{b}}$ & $4.03^{\mathrm{b}}$ & $4.55^{\mathrm{a}}$ & $4.17^{\mathrm{ab}}$ & 0.14 & $*$ \\
Abdominal fat & 74.34 & 74.58 & 73.66 & 73.57 & 78.05 & 1.48 & Ns \\
\hline
\end{tabular}

$a, b, c$ means in the same raw with different superscripts in the same raw are significantly different.

*significance, $(p \geq 0.05)$, N.S.:non-significant,

$* *$ Total edible parts $=$ hot carcass weight + giblets weight .

Table (5): Effect of dietary treatment on carcass parts percentage.

\begin{tabular}{lccccccc}
\hline & \multicolumn{9}{c}{ Treatments } & \multicolumn{2}{c}{$\begin{array}{c}\text { Significant } \\
\text { of } \\
\text { Items }\end{array}$} & Control & $\mathrm{T} 1$ & $\mathrm{~T} 2$ & $\mathrm{~T} 3$ & $\mathrm{~T} 4$ & $\mathrm{SE}$ & \begin{tabular}{c} 
differences \\
\hline Breast
\end{tabular} & 45.23 & 44.21 & 47.47 & 44.87 & 44.72 & 2.45 & $\mathrm{NS}$ \\
Thigh & 27.20 & 28.90 & 27.57 & 29.10 & 28.64 & 1.47 & $\mathrm{NS}$ \\
Drumstick & 15.51 & 15.60 & 14.17 & 15.28 & 15.13 & 0.96 & $\mathrm{NS}$ \\
Wing & 11.95 & 11.42 & 10.77 & 10.75 & 11.50 & 0.69 & NS \\
\hline
\end{tabular}

N.S.:non-significant

Table (6): Effect of different dietary treatments on economic evaluation

\begin{tabular}{lccccc}
\hline \multirow{2}{*}{ Items } & \multicolumn{5}{c}{ Treatments } \\
\cline { 2 - 6 } & Control & $\mathrm{T}_{1}$ & $\mathrm{~T}_{2}$ & $\mathrm{~T}_{3}$ & $\mathrm{~T}_{4}$ \\
\hline Average feed intake (kg) & 2.811 & 2.826 & 2.649 & 2.740 & 2.840 \\
Feed cost/chicken (LE) & 15.90 & 16.26 & 16.31 & 18.24 & 21.27 \\
Total cost/chicken (LE) $^{*}$ & 30.90 & 31.26 & 31.31 & 33.24 & 36.27 \\
Live body weight (kg) $_{\text {Total return (LE) }}^{* *}$ & 1.569 & 1.709 & 1.662 & 1.719 & 1.780 \\
Net return (LE) & 42.363 & 46.143 & 44.874 & 46.413 & 48.06 \\
Economic efficiency (EE) & 11.463 & 14.883 & 13.564 & 13.173 & 11.79 \\
Relative economic efficiency(REE) & 37.10 & 47.61 & 43.32 & 39.63 & 32.51 \\
${ }^{*}$ Totalcost & 100 & 128.3 & 116.8 & 106.8 & 87.6 \\
\hline
\end{tabular}

${ }^{*}$ Total cost $=$ cost of feeding + fixed cost (price of on day live chick, labor, medication ... etc).

*** According to the local price of $\mathrm{kg} L B W$ which was 27.0 L.E. 